\title{
The Challenge and Strategy Analysis of RMB Regionalization Against the Background of "the Belt and Road"
}

\author{
Dejun $\mathrm{Yu}^{1, *}$ Feilin $\mathrm{Luo}^{2}$
}

\author{
${ }^{1}$ Suan Sunandha Rajabhat University, Bangkok 10300, Thailand \\ ${ }^{2}$ Yunnan University of Business Management, Kunming, Yunnan 650106, China \\ ${ }^{*}$ Corresponding author. Email: yudejun2004@163.com
}

\begin{abstract}
The strategy of "the Belt and Road" has drastically increased the trade cooperation between China and the neighboring regions and also provided new opportunities for the regionalization of RMB. Based on the current situation of RMB circulation along "the Belt and Road", this paper analyzes the challenges faced by the regionalization and puts forward some suggestions to promote the regionalization of RMB.
\end{abstract}

\section{Keywords: RMB regionalization, the Belt and Road, suggestions}

\section{INTRODUCTION}

"The Belt and Road" is short for "New Silk Road Economic Belt" and "21st Century Maritime Silk Road" proposed by President $\mathrm{Xi}$ Jinping. It is a strategic concept put forward based on the complex global situation. Its core concept is openness, inclusiveness, peaceful development and mutual benefit. The implementation of this strategy will create a favorable environment and atmosphere for the economic development and social progress of our country and provide the necessary guidance and support for promoting deeper and more comprehensive cooperation and exchanges between China and its neighbors. In the process of implementing "the Belt and Road", the regionalization of the RMB will not only enhance the influence of RMB in countries along "the Belt and Road", but also elevate RMB's international status to a new level. At the same time, it will also push forward the infrastructure construction of countries and regions along "the Belt and Road" route and promote the realization of dual objectives of implementation of "the Belt and Road" strategy and RMB internationalization.

\section{THE CIRCULATION OF RMB ALONG "THE BELT AND ROAD" AND THE STATUS QUO OF ITS REGIONALIZATION}

\section{A. RMB circulation status}

In the current trade with many countries and regions along "the Belt and Road" route, China still uses the U.S. dollar as its main settlement currency and seldom settles it directly in the RMB. For these countries, RMB settlement is far less convenient than that U.S. dollar.
However, we also noticed that in some Southeast Asian countries, the proportion of RMB settlement is on the rise. Some countries even have already realized the legalization of RMB transactions in some border areas and RMB has even been used as hard currency in some countries like Vietnam, Myanmar etc. At the same time, China's financial cooperation with the countries along "the Belt and Road" route has also continued to increase. China has signed bilateral currency swap agreements with many countries and established an Asian regional foreign exchange reserve bank with ASEAN, and conducted relevant exploration on the mutual cooperation among financial institutions.

\section{B. Regionalization of $R M B$}

The continuous development of international trade and investment is an important foundation for the regionalization of $\mathrm{RMB}$ and provides strong demand for the international payment of RMB. In recent years, the economic and trade cooperation between China and other countries along "the Belt and Road" has become increasingly closer. In countries along "the Belt and Road", the import and export volume has continued to grow at a rate of more than $10 \%$ each year, while the investment is also rising. So far, China has signed currency swap agreements with dozens of countries and the amount of exchange has reached trillions of RMB. Currency swap can provide liquidity support for the import and export trade among China and those countries along "the Belt and Road" route, effectively solving the problem of financing difficulties. In 2003, Hong Kong officially became an area where RMB settlement business could be commenced. Since then, many banks have been established successively in Singapore, London and Paris for RMB settlement. The 
establishment of these banks has promoted the formation and development of RMB offshore market and boosted the international status of RMB, providing the necessary prerequisites for regional currency settlement and investment.

\section{RESTRICTIONS ON THE REGIONALIZATION OF RMB ALONG "THE BELT AND ROAD" AREA}

\section{A. Major international currencies occupies huge market share}

At present, US dollar, euro, pound sterling and the yen are still the major international currencies. Although the gap between the RMB and the major international currencies is shrinking, the RMB still has a long way to go. Meanwhile, the current mainstream international currencies will not easily give up their dominance; they will try their best to safeguard their vested interests. At present, the proportion of RMB in the global payment market is very small, and RMB faces fierce competition to surpass these mainstream international currencies.

\section{B. Imperfect market mechanism of RMB interest rate and exchange rate}

In 2005, China began to reform the mechanism of RMB exchange rate formation mechanism .So far, the exchange rate system based on market supply and demand has been initially formed. Although China has not fully allowed the RMB exchange rate to float unrestricted at present, the RMB exchange rate has been constantly changing toward free float. In 2014, China doubled the floating range of the RMB/Dollar exchange rate, greatly increasing the flexibility of RMB exchange rate. In promoting the marketization of the RMB, China has gradually achieved the marketization of inter-bank lending rates, bond issuance and RMB lending rates, and the probability of removing the deposit interest rate ceilings is also on the rise, which further aggravates the competition among the banks and is likely to lead to turmoil in the capital markets, increasing the difficulty of lending to SMEs and indirectly impeding the development of the national economy. It can be said that the pressure on the central bank to promote interest rate reform is enormous.

\section{RMB capital accounts have not realized freely convertible}

At present, China has realized the exchange of RMB under the international current account, but it still hasn't realized the free convertibility of RMB under the capital account. However, under the background of "The Belt and Road", China's foreign trade and investment scale have been continuously expanded; the demand of free convertibility of RMB under capital account is also increasing. However, subject to the restriction of the development of the country's economy and the development of the financial system, a series of conditions that allow the RMB to freely be redeemed are not yet available in China, including the development of financial market and related institutions and the ever-improving financial supervision mechanism. Although RMB is recognized in some countries along the Belt and Road, the real growth of the RMB into a regional currency requires more efforts.

\section{STRATEGY ON PROMOTING RMB REGIONALIZATION AGAINST "THE BELT AND ROAD" BACKGROUND}

\section{A. $R M B$ regionalization takes culture as the vanguard}

The regionalization of the RMB is to enable the RMB to be freely exchanged and circulated among different users in a specific area. The realization of these functions must be based on the common aspirations and interests of different countries in the region. Therefore, in advancing the regionalization of $\mathrm{RMB}$, the state should not only act according to its own wishes, but should consider the needs of all parties.

There are many countries involved in "the Belt and Road" strategy. The population of these countries varies in size and these countries have completely different political systems, religious beliefs and values. If the RMB regionalization makes other countries feel that their interests have been harmed, regionalization of RMB will inevitably be hit by other international currencies and resulting in a massive boycott by countries and regions along "the Belt and Road" route. As a result, the regionalization of the RMB will inevitably be seriously hindered. Therefore, the promotion of RMB regionalization should be a steady move. Only by setting the positive image of RMB in the countries along the "Belt and Road" can they feel that $\mathrm{RMB}$ regionalization is a win-win situation, so that $\mathrm{RMB}$ can continue to play its due role.

\section{B. Promoting regional trade scale and structure level}

Whether a country's currency can develop into an inter-regional currency or even an international currency, the country's economic strength has played a decisive role. It should make full use of the opportunities created by "the Belt and Road" and actively carry out economic and trade cooperation with other countries along the route, jointly promote the development of multilateral trade and actively promote the expansion of trade scale and the improvement of the trade structure. The trade between China and the countries along "the Belt and Road" is still dominated by intensive industries such as resources and labor while the industries that are closely related to capital and technology are still very inadequate. This also 
results in the high proportion of low value-added products in the export trade, making it difficult to form a sufficient competitive advantage in the trade. Therefore, the continuous improvement of the trade structure and the competitiveness of China's export products will make it possible for RMB regionalization to go more smoothly.

\section{Providing a smooth channel for RMB backflow}

China's trade with neighboring countries along "the Belt and Road" has been in deficit. This has led directly to the flow of RMB through the import of various kinds of goods and products from these countries. However, the RMB has not yet been fully liberalized. Foreign countries usually want to have a smooth return mechanism after they receive payment of $\mathrm{RMB}$ in China. The establishment of an offshore RMB system can effectively solve the problem of RMB investment and trade. At present, China has set up a RMB offshore financial center in Hong Kong, which provides an effective channel for China to expand the breadth and depth of the offshore RMB financial market. This series of measures will make the RMB an important means for the countries and regions along "The Belt and Road" route to balance international payments and currency reserves and will effectively promote RMB regionalization.

\section{Improving the financial market system}

The deep reform of the financial system should focus on the following aspects: First, it is to speed up the market-based reform of interest rate. Financial markets where interest rates are not liberalized will affect the price of funds and thus restrict the expansion of the RMB in the region and its acceptance by countries and regions along "the Belt and Road "route. Second, it is to perfect the formation mechanism of the RMB exchange rate market. The formation of the exchange rate market can effectively promote the scientificity of the price, enhance the independence of monetary policy in our country and enhance the flexibility of RMB. Third, it is to steadily realize the free exchange of RMB. At present, the RMB has not yet been freely convertible under the capital account. Therefore, other countries hold many concerns about holding or using the RMB, making it difficult for RMB to become the main pricing and trading mode and even harder to become the preferred way of investment and currency meeting. Final, establish and improve the financial market system. Only by establishing a sound financing system, promoting the complementarities between direct and indirect financing, improving the financing structure and coordinating development can the RMB obtain better conditions for regional development.

\section{E. Reforming the regulatory system in the process of $R M B$ regionalization}

An effective financial regulatory system is very helpful for the progress of RMB regionalization. To effectively exert this regulatory role, following measures should be taken: First, continuously promote market-oriented reforms. If we want to allow RMB to play its role in the regional development along "the Belt and Road", we must effectively ensure the independence of the functions of the financial regulatory department, give full play to its restraint on the financial markets; second, build a dynamic regulatory system for RMB regionalization. China must combine the national conditions and learn from foreign experience to form a model of government regulation, institutional self-regulation and the common participation of exchange in supervision, and conduct the whole process management of financial transaction events in advance, during and afterwards. Third, improve the financial legal supervision system. The law can provide legal protection at the legal system level by controlling the various problems arising from RMB regionalization. Fourthly, actively carries out international financial cooperation. At present, there are widespread problems in the international financial management institutions such as asymmetric information, lack of information communication and coordination among agencies, which pose a huge obstacle to the regionalization of RMB in China. Therefore, in the process of advancing the regionalization of RMB along "the Belt and Road", attention should be paid to the establishment and improvement of information sharing institutions, which not only enhances the regulatory capacity of domestic financial institutions, but also enhances the international status of RMB.

\section{CONCLUSION}

The role of RMB in pricing and settlement is becoming more and more obvious in the implementation and promotion of "the Belt and Road" strategy. At the same time, the implementation of this strategy has also created favorable conditions for the regionalization of RMB. Therefore, if China continues to expand its trade cooperation with countries and regions along "The Belt and Road" route, promote the continuous improvement of financial markets and regulatory systems, speed up the marketization of interest rates and exchange rates and realize the free convertibility of RMB capital account, RMB will give full play in the future along with the implantation of " The Belt and Road" Strategy and truly become competitive reserve currency among the countries and regions along "The Belt and Road" route, thus achieving the regionalization and internationalization of RMB. 


\section{References}

[1] Liu Rui, Cui Huatai, Xi Chun. Route of RMB Regionalization under the background of "One Belt, One Road" strategy [J]. Learning and Exploration, 2015 (11): 99-105.

[2] Wang Fang, Zhang Ce, He Qing, et al. Can RMB regionalization promote trade integration? [J]. International Finance Research, 2017, 363 (7): 86-96.

[3] Li Yong, Yuan Xiaoling. Research on RMB Regionalization in the Ancient Silk Road Area from the Perspective of Optimal Currency Area - A Case Study of 10 Eurasian Countries [J]. Economic Survey, 2017 (3): 55-61.

[4] Wang Dingbao. Qujing docking "Belt and Road" strategy development path [J]. Urban and Rural Construction, 2016 (5): 63-64.

[5] Yunnan Bureau of Statistics. 2012 Yunnan Statistical Yearbook [J]. 2012.

[6] Quiet. Portal and hub of Yunnan in the west to open the position and role $[\mathrm{J}]$. Guangming Daily 11 Edition: Famous Bright Forum, 2015.

[7] Zheng Baohua. Building an Industrial New District in Yunnan as an Engine for a Strong Industrial Province [J]. Socialism Forum, 2013 (4): 13-14. 